\title{
THE INTERFERENCES OF SASAK LANGUAGE ON ENGLISH VOCABULARY MASTERY
}

\author{
${ }^{1,2}$ Sugianto \& ${ }^{1}$ Kamarudin \\ ${ }^{1}$ English Lecturer, FBMB, Mandalika University of Education, Indonesia \\ ${ }^{2}$ Corresponding Author Email: sugianto@ikipmataram.ac.id
}

\begin{tabular}{l}
\hline \hline Article Info \\
Article History \\
Received: December 2020 \\
Revised: December 2020 \\
Published: January 2021
\end{tabular}

Keywords

Language Interference;

Sasak Language;

English Vocabulary;

\begin{abstract}
The article is aimed at revealing some crucial languags interferences that happened to Sasak students who were learning English. The Sasak itself is a subAustronesian language spoken by most citizens who live in Lombok and half of western Sumbawa. These language interferences play very important roles either in helping the students mastering eng English or challenging them. The positive interferences brought easiness to the students of Sasak to master English vocabularies. On the other hand, the negative interferences caused difficulties for students to learn English as their second language.The article say that defining the language interferences between Sasak and English brought some positive effects, particularly it is a real endeavor to help the lecturers, teachers, and instructors of English in conducting the teaching and learning practices. The research was conducted for the sake of findingpieces of evidences of these interferences issues. The interview was conducted by involving Sasak students who were learning English. Moreover, a writing test of vocabulary was also conducted to confirm the existance of language interferences when they are producing English words. Went through the research, it was concluded that some morphemes that exited in the Sasak were a lot similar to morphemes existed in English. Positively, this fact brought good effects on students who were learning English. Unfortunately, the accent in pronouncing those words was completely different, which then challenged the students to master the English vocabularies.
\end{abstract}

How to cite: Sugianto \& Kamarudin. (2021). The Interferences of Sasak Language on English Vocabulary Mastery, JOLLT Journal of Languages and Language Teaching, 9(1), 99-104. DOI: https://doi.org/10.33394/jollt.v\%vi\%i.3235

\section{INTRODUCTION}

The article begins with Sasak language interferences on Sasak language study. This issue leads into an investigation conducted by involving the students of Sasak who were learning English. The investigation was needed to provide scientific evidence of how Sasak language can affect the vocabulary mastery in learning English .This issue became critical to help students mastering English vocabulary among different cultures exist between English and Sasak. This endeavor shows how important an aspect of learning "vocabulary mastery" role in English language study (Harmer, 1998).

By and large, vocabulary is an essential foundation of a student learning English. Without mastering vocabulary, it is impossible for the students to be able to speak any sentence (Brown, 2003). Vocabulary is not only needed in listening and speaking but also needed in reading English text. Reading without mastering vocabulary used in the text is the same with reading without knowing what you read for because one cannot grasp what messages actually deliver in the text. That also happen in speaking and listening, one cannot grasp the messages deliver by someone through his/her speech till you know the vocabularies have just said by the speakers. 
In relation to the language teaching matter, teachers also have to provide and select the most appropriate method in teaching their students. However, almost every English teacher admitted that it is not an easy job to do since teaching English as a foreign language still faces a lot of problems. Those problems found commonly come from the teaching and learning process which involve problem in method of instruction, teaching media, materials and method of teaching or teaching strategy (Harmer, 1998).

Knowing that there are so many problems faced both by the teacher and students of Sasak who learning English, the researchers are now insisting to dig up more findings and evidences on language interferences through the research to information on the possible difficulties woud be faced by students of sasak in learning English language. One of endeavors here was made through the research which is aimed at enriching the learning material of English and even to compare between students' mother tongue and target language being learned for the sake of English material rematch with the source language mastered by the students.

In accordance with the above explanation, the research questions were then asked "what error does the students make on vocabulary that interfered by the mother tongue (Sasak language)?" and "does contrastive analysis between Sasak and English language solve the language interference made by the students?" Through this research, significances contribute to some like teachers and language instructors dealing with the information about the interferences affected vocabularies of Sasak students learning english that hopefully contributes much on helping them in aiding the teaching of English.

Sasak language itself is a language spoken primarily by sasak technique "dengan sasak" or sasak speakers' who majority lived in Lombok Island and used as the "mother language" the first language in daily conversation, and commonly grouped into "bahase alus" and "bahase biase" where bahase alus is the property of the "menak" noble group which has lexical differentiation for the high style, and bahase biase refers to ordinary group (Mahyuni, 2006).

Sasak language has various kinds of dialect that sometimes intelligible between others dialect. Based on the data, sasak language divided into seven dialects, Kuto-Kute (Around Bayan, and North Sasak), Ngeto-Ngete (Around Suralaga and Sembalun), Meno-Mene (Around Praya, Central Sasak), Ngeno-Ngene (Central east to north coast, and Central West coast Sasak), Mriak-Mriku (Central South Sasak around Bonjeruk, Sengkol,and Pujut), MenuMeni (Central, and Shout East Sasak), Menung-Mening (Central East Sasak). These indicated that the term "Sasak" always refers to regional variation (Mahyuni, 2006).

One of the vocabulary made process is by adding affixes into the main word of a particular language. The Affix itself is the morphological process in which bound morphemes are attached to roots or stems to mark changes in meaning, part of speech, or grammatical relationships. Affix falls in the scope of Morphology, where bound morphemes are either roots or affixes (Hadijah, 2010).

The formation of adjectives in the English language are devided into two major groups, namely adjectives, are formed by nouns and adjectives are formed by the verb. In contrast, it was also described several types of adjective-forming affixes attached to nouns, verbs, and forms the root-bound. The formation of vocabularies is categorized into the standard process of "vocabulary made" in which there is another process also been well known to perform new words or vocabularies, the process is known as a derivational process. Derivation is the process adding derivational morphemes that change word category, part of speech, and the meaning of the previous word (Ratna Y.A, 2008).

In Sasak Language this term is really productive in fact we can mention many examples of derivational morphemes, to make it evidence lets compare these examples Changing Noun become adjective, Kepeng "money" become bekepeng "rich" 
Changing noun become verb Lagu "song" become belegu "singing"From these two examples we can conclude that by adding the derivational morphemes such "be" may change the meaning and category of the previous words, and also indicated that the Sasak Language has morphological process in it.

\section{RESEARCH METHOD}

The research method applied in the study of first language interferences is the qualitative research method. The researcher conducted interviews to find out research evidence of Sasak language interferences on English language study and vocabulary mastery in particular. This type of research method, a qualitative research method was used by many researchers to collect and analyze qualitative data to understand a particular concepts and phenomena (Arikunto, 2002)..

\section{Research Design}

The research design used in this study is descriptive qualitative research design. Using this particular research design, the researcher conducted the interview to find what kinds of language interferences were mostly happened and make sure that those language interferences were made because of the first language interferences. In addition, the researcher also conducted a writing test of vocabulary to make a confrontation between what were found in the interview confirmed in a vocabulary writing (Creswell, 2008).

\section{Object}

The research object of the study is Sasaknese or Sasak language Menu Meni dialect in particular in which the research participants were taken from the students of Mandalika University of Education who were taking English Language Teaching Major. Indeed, five research participants were interviewed to find out the language evidences on how a mother tongue, Sasak language in particular, interfere the English language, vocabulary mastery.

Mahyuni (2006) asserted that Sasak language itself is one of the local languages spoken among Sasak people in Lombok. It is used as a means of communication by the Sasak ethnic group, inhabiting Lombok islandwhich makes up most of the population of Lombok. Sasak language is the first native language after Indonesian, used by most people on Lombok island in their daily communication.

Sasak language has various dialects, in which every dialect is spoken according to three main castes or context of speaking. Those three contexts are Soft language or noble language is the language used by a group of nobles, The Madya language or intermediate language is a language that has been entered by soft language, used by the middle class, Ordinary language is the language used by the group or the general public rows of coral (Mahyuni, 2006).

\section{Instruments}

The instrument of a research is all means and media used by the researcher to collect the research data (Sugiyono, 2008). Here in this research, the researcher used an interview sheet as an instrument. The interview sheet guided the researcher in interviewing the research participants, giving the information of what should and what should not to be collected in the research, meaning that the data related

\section{Data Analysis}

Sugiyono (2014) said that the data analysis of a language study refers to how the researcher present, display and conclude the data collection of a research. The data found during the study progress was alayzed by adapting the model of data analysisby Penny Ur (1991) who described the data analysis on qualitative research must involve the following 
points, those are dealing with "what people say?" "what people do?" and "what people left behind?"

Interview transcription refers to the process of transcribing the whole data results which were gained from the interview conduct. The results of interview listened and analyzed the full recording before transcribing, calculate how long it take, pick the right tools and construct a transcribe a draft. In this phase of data analyzing technique, the researcher may also involves the proof reader to make a proofread and short-cuts to save time. The next phase of data analysis is data display, the data display means the show of the whole data gained from the whole research instruments interview guidance and observation sheet. The display of data performed tables. All are designed to assemble organized information into an immediately accessible, compact form so that the analyst and readers can see what is happening and justified conclusion.

The last stream of analysis activity is conclusion drawing. The conclusion provides explanation to the readers about what exactly the research means based on the data finding. Drawing conclusion of the research also provides opportunities to the readers to explore the detail implications of the findings.

\section{RESEARCH FINDINGS AND DISCUSSION Research Findings}

The study on first language interferences of Sasak students learning english leads into the findings that vocabularies made a pattern in Sasak language may affect he understanding of vocabularies mastery in the target language, English language. A word can be used as a basis for the formation of other words with certain rules. In this case, the formation of verbs derivative are formed through other types of word classes. In its distribution, the formation of verbs derivative can be formed through verbs, nouns, and adjectives. Even the derivational process is also found in vice versa.

Conversely, in Sasak language there are three types of an affix to perform the new word from an existing word. The types of affixes are prefix, simulfix, and suffix. Those affixes are described through the examples of the formation of the wordsSasak language. The descriptions are found the table 1 below.

Table 1

The sasak words transformation interferences

\begin{tabular}{ccc}
\hline Prefix & Suffix & Simulfix \\
\hline$t e-$ & $-a \eta$ & $t e-a n$ \\
\hline$p e-$ & & \\
\hline$b e-$ & & \\
\hline$m e-$ & & \\
\hline
\end{tabular}

\section{Discussion}

Affixes are the attachment of words-elements into the steam of words to perform new meanings or new words classes. The first affix that attached at the beginning of a word or prefix that can form verbs in Sasak language is prefix te-. The function of prefix $t e$ - in Sasak is to form "passive voice" or to make the verb become passive. Examples can be found in words "palang" into "tepalang" or "paling" into "tepaling" which mean "steal" into "stolen"

The second affix that attached at the beginning of a word or prefix that can form verbs in Sasak language is prefix pe-. The function of prefix te-in Sasak is to form the meaning "to cause something become". Take a look at the affixation process of verb with the following prefix. The example of words derived from prefix "pe-," are "tukah" into "penukah", "kuat" into "pekuat" which mean "strong" into "strengthen". 
The next form of affix that attached at the beginning of a word or prefix that can form verbs in Sasak language is prefix be-. The function of prefix be-in Sasak is to form the verb become intransitive verb, which means if the verb is used in a sentence, the verb does not need an object. Take a look at the affixation process of verb with the following prefix. Example of words are like "gawe" into "begawe" or "regaq" into "beregaq" that means "bargain" into "bargaining".

The next affix that attached at the beginning of a word or prefix that can form verbs in Sasak language is prefix me-. The function of prefix me- in Sasak is to tell about prent action. Take a look at the affixation process of verb with the following prefix. The examples of words are "mongkaq" into "memongkaq" which means "cook" into "cooking".

And then the last is sufix and the only affix that attached at the end of a word or suffix that can form verbs in Sasak language is suffix - $a \eta$. Suffix - an can form the meaning of "causing" and also this suffix has another function to form benefactive verbs. That is, the work or activity intended by the verb is done for someone else not for the role of the subject or agent. The examples of words are "piaq" into "piaqan" which means "make" into "made".

The first and the only affix that attached at the beginning and at the end of a word or simulfix that can form verbs in Sasak language is suffix simulfix te - an. The function of simulfix te-an in Sasak is to form "passive voice" or to make the verb become passive. The example of words are "jauq" into "tejauqan" or taeq into "tetaeqan" which mean "getting up" into "get something up".

\section{CONCLUSION}

The research finding of the study says that there is some significant similar pattern of how sasak language formation of new words or vocabularies by adding affixes. The similarities of both languages Sasak and English reflected through how the words are perform in affixation. These similarities then interfer the students who were learning english to master the vocabularies that have similarities quicker and easier than mastering the words that has no similar pattern in their first language, sasak language.

The study cconcluded that both Sasak and English undergo word-formation process through derivational process in which it is said that both Sasak and English have derivational process to perform a new word. It means that this derivational process innterfer the students' vocabulary mastery when learning english.

On the other hand, some differences between sasak language and english language brought negative interference where the students found it difficult identify "simulfix" term in english. In addition, the students of sasak learning english found it difficult to identify some prefix and suffix which are not similar to what the found in Sasak language. It was known that the study reported Sasak has only one suffix while English has four suffixes. Mostly, English suffix can be attached to the word class adjective and noun except for suffix /-ate/ which has special circumstances where this suffix is attached to the bound morpheme.

In relation to derivational process happened in both language, Sasak suffix is able to be attached to almost all word classes except adverb because this suffix is the most productive suffix in Sasak. This suffix can be attached to noun, adjective, verb, and adverb. In terms of meaning of affix in both Sasak and English language. Most of them are different except for prefix /pe-/ in Sasak and prefix /en-/ in English. The function of prefix /te-/ in Kuto-Kute dialect is to form a passive verb or passive voice. 


\section{REFERENCES}

AlTiyb A.K. (2013) Comprehension Strategy Instruction in Language Learning Classrooms: Selecting and Using Children's Picture Books for Explicit Reading Comprehension Instruction. International Journal of English Language Teaching (IJELT) 4(4), 829-837.

Boum, Y. (2020) Aspects of English grammar to be reinforced in the teaching of English as a second or foreign language. European-American Journals. 7(5), 114-121.

Brown, H.D. (2003). Language Assessment: Principles and Classroom Practice. San Francisco. Longman.

Creswell, J.W (2008). Educational Research; Planning, Conducting, And Evaluating Quantitative And Qualitative Research. Boston. Pearson international edition.

Er, S. (2014). Which is the Most Appropriate Strategy for Very Young Language Learners? International Journal of Social Sciences and Education, Educational Researches Journal. 7(3), 114-118.

Imran, F. (2008) An Error Analysis on the Use of Grammatical Items In Simple Paragraph: A Case Study: At the second Year Students of MA NW For Boys Narmada in Academic Year 2007/2008. Mataram. Unpublish Thesis of IKIP Mataram.

Hadijah, S. (2010). A Study on Passivization in Sasak "Meriak-Meriku" Dialect: a Case Study at Batu-Tulis Village of Central Lombok Mataram: English Department of mataram institute of teacher training unpublished thesis.

Warta, K. (2010) Nominal and Verbal in Dialect Sasak Kuto-Kute Bayan, West Lombok Regency:Description and analysis. IKIP Mataram: Unpublish Thesis.

Mahyuni. (2006). Speech Styles and Cultural Consciousness in Sasak Community. Mataram: Yayasan Cerdas.

Orsel, C. \& Balikesir, F.Y. (2016). A Comparative Study on English Language Teaching to Young Learners Around the World. Contemporary Research Journal. 7 (3).114-118.

Penny Ur (1991). A Course in Language Teaching. Cambridge: Cambridge University Press, Cambridge: Cambridge.

Raja, P. (2012) The Language of an Indonesian Child Named Mika in the Telegraphic and Simple Sentence Stages. Unpublished doctoral dissertation. Malang: Universitas Negeri Malang.

Ashriany, R.Y. (2008). Sistem Verba Bahasa Sasak Dialek Bayan Dari Dasar Verba Dan Nomina. Thesis. Universitas 11 Maret Surakarta.

Dolati, R.I., Mousavi, S.N. (2014) Non-native speaking learners (n.n.s.l) strategies (metacognitive, cognitive and affective strategies). Journal of English Language Teaching (IJELT) 4(4), 829-837.

Sugiyono. (2008) Metode Penelitian Pendidikan, Pendekatan Kualitatif, Kuantitatip R\&B. Bandung: CV. Alfabeta.

Sugiyono. (2014) Metode Penelitian Pendidikan. Bandung: ALFABETA,CV.

Suharsimi A. (2002). Research Procedure; Prosedur Penelitian. Edisi ke V. Jakarta. Rineka Cipta.

Suryati, N. (2005) Teaching Various Monologue Texts. A paper presented in One-Day Workshop on Making the Most of Various Monologue Texts in the Teaching of English. Malang. State University of Malang.

Yule, G. (2006) TheStudy of Language: Third Edition. Cambridge University Press. 